\title{
MISOGINIA ESTÉTICA EN EL «ART \\ NOUVEAU». EL MIEDO A LA MUJER NUEVA \\ EN LA SOCIEDAD DE «FIN-DE-SIGLO»:DE \\ LA SALOME DE HUYSMANS A LA LULÚ DE WEDEKIND
}

\section{ART NOUVEAU AND AESTHETIC VIOLENCE AGAINST WOMEN. FEAR OF THE NEW WOMAN IN FIN DE SIĖCLE SOCIETY: FROM SALOME (BY HUYSMANS) TO LULU (BY WIDEKIND)}

\author{
José María Seco Martínez \\ Universidad Pablo de Olavide, Sevilla, España \\ jmsecmar@upo.es
}

Recibido: septiembre de 2021 Aceptado: noviembre de 2021

Palabras clave: Art nouveau, violencia estética, sufragismo, decadentismo, expresionismo, femme fatale Keys words: Art nouveau, aesthetic violence, suffragism, decadetism, expressionism, femme fatale

Resumen: En el tránsito del s. XIX al XX confluyen en Europa movimientos y tendencias intelectuales de toda laya (socialismo, anarquismo, regeneracionismo, espiritualismo, krausopositivismo, etc), junto a tendencias artísticas como el esteticismo, el decadentismo, el simbolismo, el modernismo literario, el expresionismo, etc..., como un reflejo del estado espiritual de la época, de pose anti-burguesa y profundamente antipositivista. A esta eclosión intelectual y cultural se la conoce bajo la expresión "fin de siècle" y está asociado a las corrientes esteticistas, influidas por la filosofía nietzscheana, que se agruparán bajo la expresión "art noveau"; corrientes diversas entre sí pero coincidentes en su actitud discriminatoria hacia las mujeres. En este trabajo analizamos su influencia en el nacimiento de un nuevo estereotipo femenino, vinculado a una imagen de la mujer especialmente ominosa y exagerada del mal, que acabará poblando a través de la bohemia artística y literaria de la época el imaginario estético del siglo XX. Ahora el rechazo a la mujer nueva se dirime en el campo de la imagen y de las palabras.

Abstract: In the transition from the 19th to the 20th century, intellectual movements and trends of all kinds (socialism, anarchism, regenerationism, spiritualism, krausopositivism, etc.) converged in Europe, together with artistic trends such as aestheticism, decadentism, symbolism, literary modernism, 
expressionism, etc., as a reflection of the spiritual state of the time, with an anti-bourgeois and profoundly antipositivist attitude. This intellectual and cultural hatching is known under the expression "fin de siècle" and is associated with the aesthetic currents, influenced by the Nietzschean philosophy, which will be grouped under the expression "art noveau"; diverse currents among themselves but coinciding in their discriminatory attitude towards women. In this paper we analyze their influence on the birth of a new feminine stereotype, linked to a particularly ominous and exaggerated image of evil, which will end up populating through the artistic and literary bohemia of the time the aesthetic imaginary of the twentieth century. Now the rejection of the new woman takes place in the field of image and words.

\section{l. Introducción}

La existencia del patriarcado se nos muestra hoy como algo incuestionable ${ }^{1}$,

1. Incuestionable sí, pero con diferencias dependiendo de las distintas interpretaciones que desde los feminismos se han hecho del Patriarcado. Así para el llamado feminismo liberal (V., por ejemplo, Friedan, B., The Femenine Mystique, New York, Penguin, 1963; o también Moller Okin, S. "Liberalismo político, justicia y género", en Castells, C. (ed.), Perspectivas feministas en teoría política, Barcelona, Paidós, 1996) el patriarcado ha sido superado merced a las revoluciones burguesas de los siglos XVIII y XIX, en la medida en que consiguieron traer la igualdad de derechos, si bien considera siguen vigentes todavía determinados prejuicios y no pocas exclusiones. Por eso fía las soluciones a la igualdad y al principio de oportunidades para todos. Para el feminismo "socialista" o "marxista" (V. Hennessy, R., Ingraham (ed.), (1997), Materialist Feminism. A como ha elucidado de sobra la ontología feminista, que alcanza a todos los espacios de la vida ${ }^{2}$, supeditando a las mujeres en todos los planos. Es mucho más que una cultura androcéntrica de encierros aislados y diferenciados, que excluye a las mujeres y disciplina sus cuerpos. Es una visión antropológica del mundo que prefigura las relaciones sociales desde la subordinación y la desvalorización de lo femenino, como si de una verdad irrefutable se tratara, como algo natural ${ }^{3}$. La in-

Reader in Class, Difference, and Women's Lives, London, Routledge, 1997; o también Jaggar, A. M. "Socialist Feminism and Human Nature", en Sterba, J. P., Justice. Alternative Political Perspectives, Belmont, Wadsworth Publishing Company, 1992) el patriarcado opera junto al espacio de la producción, de modo que mientras no se cambien las relaciones entre capital y trabajo, no será posible la caída del patriarcado. Producción y patriarcado han jugado una papel crucial en la perpetuación de las relaciones de dominación entre hombres y mujeres; $\mathrm{y}$, por último, el considerado feminismo "postcolonial" (sobre todo Bell, H., "Black Women: Shaping Feminist Theory", en James, J., y Sharpley-Whiting, T. D., The Black Feminist Reader, Oxford, Blackwell, 2000) considera, que ambas opciones no han prestado suficiente atención a la centralidad que el patriarcado asume en el diseño de las relaciones sociales. El patriarcado es un orden de valores que articula relaciones de dominación económicas, étnicas y de orientación sexual; y reprocha a ambos que hayan impulsado espacios de emancipación para la mujer, sin reparar en la diversidad de usos culturales del mundo y en la necesidad de que sean las propias mujeres las que, desde sus propia matriz cultural, las que sigan una estrategia de guerra a los esquemas patriarcales.

2. Simón Rodríguez, E., Democracia vital. Mujeres y hombres hacia la plena ciudadanía, Madrid, Narcea, 1999, p. 19

3. Como un sistema de ingeniería social que propone y ejerce el control sobre "la reproducción social de las mujeres" Boaventura, S., Crítica de la razón indolente, Bilbao, Desclée de Brouwer, 2003, p.325. 
terpretación que la antropología androcéntrica ha hecho de la división histórica del trabajo entre hombres y mujeres, excluyendo a la mujer del espacio de la producción y confinándola a la soledad silenciosa del hogar, es sólo el exponente de una tradición mucho más amplia que supedita a la mujer como un hecho natural.

Cabe entonces preguntarse, iexiste un nexo de unión entre las diferentes mujeres en la historia? Podría decirse que sí. La maternidad, el cuidado de niños, la atención a ancianos y a enfermos, la satisfacción de las necesidades materiales y sexuales de los hombres, han sido tareas encomendadas de manera tradicional a las mujeres. Unas tareas que han sido definidas por los hombres y que están marcadas por la abnegación. Unas tareas destinadas al silencio y que no merecen ser contadas. Condenadas a ser meros testigos sin valor, las mujeres han permanecido ocultas y sin conciencia de sí mismas; aisladas unas de las otras y en espacios muy limitados -desde el Gineceo griego a la habitación que describiría Virginia Wolf ${ }^{4}$.

El patrón patriarcal ha construido el mundo siempre a espaldas de las mujeres. El hombre ha estado per se en la vida social, donde queda instalada la política, el sa-

4. Recordemos sino a Virginia Woolf y los problemas que planteaba ante la falta de espacios: la mujer no dispone de una habitación propia donde crear, viajar y vivir sin ninguna tutela. Carece de un espacio donde llevar a cabo el deseo humano de ser autónomo, en un mundo que le pertenece tanto como al hombre. Forrester, V., Virginia Wolf. El vicio absurdo, Madrid, Ultramar, 1977, p. 69. De hecho es la propia Virginia Woolf la que en Tres guineas denuncia la discriminación que padece la mujer a todos los niveles. La mujer permanecerá atrapada en ellos y subsumida en la vida del hombre, que viene a nuclear su existencia. Heilbrun, C., Writing a woman life, New York, Ballantine, 1988, p. 21. ber, lo militar y lo religioso, como sus campos exclusivos. A la mujer, en cambio, se le ha reservado el ámbito de "lo natural" y se le ha negado "lo cultural" ${ }^{5}$, apropiándose primero de sus tiempos y espacios para olvidarla después borrando sus huellas, arrancándole así cualquier conexión con la verdad histórica -anexa siempre a principios abstractos y masculinos- y relegándola a los espacios intocables de la familia y de la religión, que consagran el dominio patriarcal.

Esta ideología ampliamente dominante que invisibiliza a las mujeres y que se presenta como natural -pero que es convencional e histórica- ha estado siempre ahí. Desde la antigüedad clásica los hombres han determinado qué son las mujeres y cuáles son sus deberes. La dominación masculina 6 siempre se ha ejercido accediendo y disciplinando sus cuerpos; ha variado en sus formas, pero ha seguido por encima de todo, como una seña de identidad, trasmitiéndose entre generaciones como un recado o una herencia, como una especie de transverberación que no termina nunca del todo, porque hunde sus raíces "en un episteme común"7, que

5. Reeves, P., "The Reproduction of Patriarchy in Feminist Anthropology", en McCanney Gergen, M., (ed.), Feminist Thought and the Structure of Knowledge, New York University Press, 1988, p. 54.

6. Una dominación que las propias mujeres han venido asumiendo, aceptando inconscientemente su inferioridad. Véase sino a Bourdieu, P., La dominación masculina, Anagrama, Barcelona, 2021. El abordaje de Bourdieu aquí es etnográfico, centrándose en la sociedad cabileña, léase el norte de Argelia y el Magreb, pero ofrece herramientas muy potentes para elucidar el alcance de las estructuras simbólicas de la dominación androcéntrica.

7. Duby, G., y Perrot M., "Escribir la historia de las mujeres", en Historia de las mujeres, Barcelona, Circulo de Lectores, 1994, p. 11 
se apuntala en la necesidad de someterlas para extraer el potencial productivo de los hombres 8 . Ha estado en el mundo greco-romano, en el cristianismo, en el Renacimiento y en la Reforma, en los procesos revolucionarios de la modernidad (democratización, pluralismo, politeísmo de valores, etc), pasando por, si se nos permite la expresión, por el feminicidio estético del último tercio del s. XIX, un período donde la "guerra contra la mujer" se dirime sobre todo en el campo de la imagen y de las palabras 9 .

8. (....) y cuya espuria gratificación era, en última instancia, el acceso y dominio sobre el cuerpo de aquéllas" (Solórzano, N., "Algunas claves para el una crítica de la imaginación jurídica. De los obstáculos epistemológicos en el derecho moderno y su ciencia", en Seco., J.M (ed), Esferas de democracia, Sevilla, Aconcagua, 2004, p. 163). Nótese como se pronunciaba hasta el mismo Rousseau en el Emilio o de la educación, dirigiéndose a Sofía: "Dar placer a los hombres, serles útiles, hacerse amar y honrar por ellos, criarlos de jóvenes, cuidarlos de mayores, aconsejarlos, consolarlos, hacerles agradable y dulce la vida; he aquí los deberes de las mujeres en todos los tiempos, y es lo que se les ha de enseñar desde la infancia"; como también lo haría el mismo Lutero dos siglos antes en plena Reforma, cuando explicaba a la mujer mediante la metáfora del nido, en una especie de reclamo arcaico a esa especie de placenta que es siempre la mujer, evocando así su poder regenerador; y que se prodigaría desde el Renacimiento a través de imágenes como la caracola, la nave, la concha..., etc.; una metáfora hermosa, que sobrevivirá incluso a la modernidad, a través del romanticismo y que se sintetiza en la idea del cuidado regenerador a través de la sexualidad y la maternidad. Y que inspiraría, por ejemplo, a poetas como Claudel, Saint-John-Perse o Paul Valery; o como también se pronunciaría también mucho antes el obispo de Limerick, en plena Edad Media, cuando decía que las mujeres no tenían otro afán que el matrimonio para servir a quienes oran, trabajan o combaten; y así sucesivamente hacia atrás en la historia...

9. Dijkstra., B., Dols of Perversity: Fantasies of Feminine Evil in Fin de Siecle Culture, Oxford., O. U. P. 1986 , p. 7
En este trabajo nos planteamos precisamente indagar en las causas por las que en este período irrumpe con fuerza un nuevo estereotipo femenino, vinculado a una idea de la mujer especialmente exagerada del mal, que acabará poblando a través de la bohemia artística y literaria de la época -especialmente a través del teatro y de la novela- y más tarde del cine y la publicidad, el imaginario estético del siglo XX. Una imagen ominosa de la mujer que revela hasta qué punto los procesos de la modernidad no consiguieron desafectar la realidad de esta visión androcéntrica del mundo. En medio de la profunda revolución de valores, de costumbres y de mentalidad que contrajo la ilustración se embozaba también una oportunidad para seguir ejerciendo el control sobre ellas, sin reconocer un estatus adaptado a su esencia, dando paso, si se quiere, a un tipo de alienación más sutil, a cuyo desarrollo contribuyó la formación de una opinión manipulada a través de las artes.

En el tránsito del s. XIX al XX confluyen en Europa movimientos y tendencias intelectuales de múltiples tonos (socialismo, anarquismo, regeneracionismo, espiritualismo, krausopositivismo, etc), junto a tendencias artísticas de vanguardia como el esteticismo, el decadentismo, el simbolismo, el modernismo literario, el expresionismo, etc..., como un reflejo del estado espiritual de la época, de pose anti-burguesa y profundamente antipositivista, merced a la acción de los irracionalismos. Significaban una nueva sensibilidad y receptividad a valores espirituales y antimaterialistas, esto es, una nueva estética de la palabra, las formas y los géneros, en cierta medida clasicista, pero también exótica. A esta eclosión intelectual y cultural que se prodigó por toda Europa, se la 
conoce bajo la rubrica "fin de siècle" y sirve para designar a toda una época, la "belle époque", que se extiende desde 1885 a 1914; se inicia en Francia con la muerte de Victor Hugo y acaba con el comienzo de la Primera Guerra Mundial; es de origen francés, pero aún así el concepto hizo fortuna a partir de1890, asociado a las corrientes esteticistas, influidas por la filosofía nietzscheana, que desaguarían en el decadentismo y, más tarde, en el modernismo. Bajo la rúbrica "fin de siglo", por tanto, se condensan lo viejo del siglo diecinueve y las expectativas de novedad que representaba la inminencia del nuevo siglo. A las artes de vanguardia que se agrupan bajo la expresión fin de siglo, se las conocerá también como "art noveau"10.

Así es, el "art nouveau" contribuirá de manera decisiva a la plasmación estética de la dicotomía femenina, representada como madre santa o como prostituta, como Madonna o Magdalena. Los personajes femeninos serán representados a partir de entonces como puros y virginales por completo, esto es, inaccesibles y carentes de pasión alguna, o ávidos de deseo y conocimiento sexual y, por tanto, peligrosos $^{11}$. La exaltarán como ángel 0

10. Aunque también se llamará "Jugendstil" en Alemania, "Modern Style" en el Reino Unido, "Liberty o Floreale" en Italia y Modernismo en España.

11. Interesantes en este sentido son las páginas de Trudgill, E. Madonnas and Magdalens: The Origins and Development of Victorian Sexual Attitudes, Londres: Heinemann Ltd, 1976, pues fue uno de los primeros en afrontar el estudio de esta dicotomía desde la literatura. V. también a Gilbert, S., y Gubar, S., The Madwoman in the Attic: The Woman Writer and the Nineteenth-Century Literary Imagination, New Haven, Yale U. P, 1984; o Showalter E., Sexual Anarchy: Gender and Culture at the Fin de Siecle. Nueva York: Penguin, 1990. musa, exhortando a las jóvenes a inspirarse en ellas (para luego desnudarlas "y examinar sus aptitudes para obtener su diploma de puta"12); hasta llegar al nacimiento de un nuevo estereotipo femenino (asociado a la irrupción emergente de los primeros movimientos feministas) también ungido desde el principio -ahora la Magdalena deja de ser un tabú para convertirse en un tótem-13 ${ }^{13}$, pero por una visión abiertamente exagerada del mal: la femme fatale

\section{Antecedentes filosóficos. La filosofía alemana}

La filosofía alemana, especialmente Nietzsche, Schopenhauer, Hegel, Feuerbach, Kierkegaard, junto a los estudios de la diferencia sexual de William James, Otto Weininger, Von Kraft Ebing, Freud y sus discípulos ${ }^{14}$, será determinante en esta construcción menospreciativa de la mujer, pues servirá de fundamento y aglutinante para no pocos escritores y artistas

12. Como ejemplificará Marie Veronique Gauthier en su Tesis Doctoral titulada Les societés cantantes au XIX siècle (Chanson et sociabilité); defendida en 1989 bajo la dirección de Maurice Agulhon. Se puede consultar en https:// www.theses.fr/1989PA010619; la referencia ha sido tomada de Duby G. y Perrot, M., Op. cit., p. 8. Es interesante el estudio que aquí se plantea pues aborda el análisis de las sociedades de canto y los coros del siglo XIX, como espacios de sociabilidad masculina en los que se traslucía la tensión de la época que aquí apuntamos, entre la necesidad de moralizar la canción y la obsesión por el discurso sexual.

13. Véase a Trudgill, E. op. cit., p. 289

14. Errázuriz Vidal, P, Misoginia Romántica, Psicoanálisis y Subjetividad femenina, Zaragoza, PUZ: Prensa Universitaria de Zaragoza, 2012, p. 372. 
en el desarrollo de sus obras, en un período, entre siglos, marcado por el repudio a los valores burgueses y la desconfianza hacia la ciencia (cuyo fracaso fue incluso proclamado en 1895 por Ferdinad Brunetière). Su pensamiento logró generar una buena prensa entre las élites intelectuales de fin de siglo, instalándose en el discurso y en el imaginario con pretensiones de naturalidad, hasta el punto de que la llamada "modernidad vienesa", esto es, la explosión cultural surgida durante el decimonónico en la capital del Imperio austro-húngaro, podría considerarse hoy el episodio más determinante en la revolución artística y filosófica que habría de venir en el siglo XX.

El hecho es que por aquellos años, la filosofía alemana era experta en crear respetabilidad, de modo que los conceptos o nociones por ella elaborados se beneficiaban de esa respetabilidad; nótese, por poner un ejemplo de esta respetabilidad, como se sincera Ramiro de Maeztu - por situarnos en nuestros maestros del 98 "confieso que Max Stirner, Schopenhauer, ...y, sobre todo, Federico Nietzsche, dirigiendo sus lógicas hacia el instinto, nos han enseñado el derrotero" ${ }^{15}$.

No es de extrañar, por tanto, que su filosofía influyera de manera crucial en la bohemia literaria y artística de la época, incidiendo decisivamente en el estado espiritual de su tiempo. El tema de lo femenino no sería una excepción, de modo que poco a poco se irán preparando las bases para una nueva imagen estética de la mujer mucho más degradada y menospreciativa. La literatura tomará de su filosofía buena parte de sus referencias, de sus criterios estéticos y sociales: la moral

15.Maeztu., R., Hacia otra España, Ediciones Rialp, Madrid, 1967, p. 234. de la fuerza, la valoración de la vida y de la voluntad frente a la razón y la ciencia, el eterno retorno, el anticristianismo, y, como no, también su visión de la mujer ${ }^{16}$. Piénsese, por ejemplo, en la generación del 98, donde la influencia de estos autores, sobre todo la nietzscheana, es palmaria ${ }^{17}$. Piénsese en autores, tan emblemáticos en nuestras letras, amén del mencionado Ramiro de Maeztu, como Pío Baroja, Azorín o Unamuno. Así, por ejemplo, en Pío Baroja, por centrarnos en el primero de ellos, la influencia de Schopenhauer es clara en la Sensualidad pervertida o en Camino de perfección (1902), mientras que la de Nietzsche se percibe netamente en César o nada (1910). En Azorín, la influencia nietzscheana es todavía mayor, y así se infiere en la trilogía que marcaría su evolución literaria: La voluntad (1902), Antonio Azorín, que marcaría el pseudónimo de utilizaría en adelante (1903) y Las confesiones de un pequeño filósofo (1904); por no mencionar al Cristo-Quijote que repre-

16. Por tanto, no puede afirmarse, como escribe Pedro Salinas, "que entre los hombres del 98 existiera un caudillo nominal y exclusivo. Pero sería difícil negar también que ideológicamente había un guía de esta generación, Nietzsche...". Salinas, P., "El concepto de generación literaria aplicado a la del 98", en Literatura española. Siglo XX, Madrid, 1970, p. 31. Para una panorámica más amplia de lo que aquí decimos interesantes son las páginas de Savignano, A., El 98 y la filosofia europea, en Anuario Filosófico, $\mathrm{n}^{\circ} 31$, 1998, pp.71-90.

17. El hecho de que a Nietzsche, por ejemplo, se le considerase al principio como un simpatizante anarquista, facilitó su incursión entre la juventud intelectual de su época, muy desafecta y desencantada, haciendo brotar en ella "gestos iracundos y gritos de protesta, impulsando a los jóvenes, que se habían hecho un Nietzsche 'para su uso', a una intensa labor". Sobejano., G., Nietzsche en España, Ed. Gredos, Madrid, 1967, p. 402. 
sentaría Unamuno desde la publicación de uno de sus libros más celebres La vida de Don Quijote y Sancho (1904); o al Pío Cid de Ángel Ganivet (1898), como un reflejo de la idea nietzscheana del súper hombre.

Lo que queremos decir aquí es que el pensamiento alemán, especialmente el de Nietzsche y Schopenhauer, insufló aires nuevos entre las élites intelectuales y artísticas de la época, ávidas de aire fresco, en un período, que coincidía con el final del decimonónico y el comienzo del siglo XX. Europa, como escribiría el propio Pío Baroja "parecía entonces una mujer vieja y febril que se pinta y hace una mueca de alegría"18. Tal era el estado espiritual de la época ${ }^{19}$, de modo que sus ideas relacionadas con la acción, la voluntad, lo telúrico, la valoración de la vida y el placer, los sentimientos, etc... permitieron dar entrada a un mundo emotivo y pasional hasta entonces supeditado por el racionalismo, la industrialización y la ética de la sociedad burguesa. Sus ideas, por tanto, calaron con rapidez en medio de una sociedad cansada y misoneísta, procurando a las artes y a la literatura, como bien escribe Sobejano, de nuevos y "fecundos impulsos" ${ }^{20}$; pero al hilo de aquellas ideas

18. Baroja P., "Divagaciones apasionadas", en Obras completas, Madrid, Biblioteca Nueva, 1946-51, p. 492.

19. Este clima espiritual fue el que hizo posible, por ejemplo, la filosofía vitalista y existencial de Unamuno y en Ortega y Gasset en España, en Henri Bergson en Francia, y en multitud de autores como Scheler, Jünger, Stefan George, Oswald Spengler, etc...

20. Como bien explica Sobejano, en lo que hace a España, Nietzsche "(...) imprimió nuevos ímpetus a un gran sector de la vida espiritual, sin llegar a apoderarse de ella íntegramente ni mucho menos a incidir en la vida material. Sus ideas ayudaron, sí, al mejor entendimiento de cierta filosofía vitalista, por Ortega representada. Re- también lo hicieron la exaltación de la dureza, la lucha y el desprecio a la mujer, en una sociedad que seguía siendo profundamente patriarcal.

El hecho es que, amen de la propia significación intelectual del pensamiento decimonónico alemán dentro del panorama ideológico de la sociedad de fin de siglo, su filosofía fue de un acusado desprecio hacia la mujer, (especialmente Schopenhauer ${ }^{21}$,

novó Nietzsche los modos de comprensión psicológica (...). Contribuyó a encauzar la política por trayectorias nuevas (...)”. Sobejano, G., Op. cit., p. 151.

21. Schopenhauer, por ejemplo, en el segundo volumen de los Parerga y Paralipómena, escribe “ la mujer no está determinada ni está destinada "a grandes trabajos espirituales ni corporales. Ella salda la deuda de la vida no mediante la acción, sino mediante el sufrimiento, mediante el dolor del parto, el cuidado del infante, y de la sumisión al hombre, del que debe ser una paciente y serena compañera" Shopenhauer, A., Parerga y Paralipómena, II, Madrid, Trotta, 2009, cap. 27, aforismo 363. Pero a esta inferioridad natural hay que sumarle la deslealtad y la injusticia en sus relaciones con los demás; recurre al engaño porque necesita protegerse. La violencia de este autor aquí abruma, pues mistifica el engaño en ella; no hay otra forma de estar siendo mujer; se dedica a él y lo utiliza "como su propio derecho" El engaño, escribe, " es innato en la mujer, lo mismo en la más aguda que en la más torpe. Es en ella tan natural su uso en todas las ocasiones, como en un animal atacado el defenderse al instante con sus armas naturales. Obrando así, tiene hasta cierto punto conciencia de sus derechos, lo cual hace que sea casi imposible encontrar una mujer absolutamente verídica y sincera". Shopenhauer, A., El amor, las mujeres y la muerte (trad. a cargo de López White), en www.schopenhauerweb.org, 2008. Cfr. también con Godet., P., $L a$ pensée de Schopenhauer, Paris, Payot, 1918, pp. 390-391.; el engaño ya no reside en la educación femenina, una educación diseñada por hombres y cuyos productos son la hipocresía, la pasividad, la mentira, la falta de espontaneidad, como ya se dejara entrever por no pocos autores ilustrados. 
Nietzsche ${ }^{22}$, Otto Weininger, etc. ) hasta llegar a producir una visión de ella, a través de las élites intelectuales y artísticas, especialmente menospreciativa, que se prodigaría rápidamente casi como un reflejo instintivo frente a lo que comenzaba

22. En Nietzsche el menosprecio a la mujer, recurrente en muchos de sus escritos, es axial en su biografía y aparece ya, desde sus años más tempranos. Es cierto que en su filosofía se detecta una cierta ambivalencia entre tendencias opuestas que se sintetizan en una especie de dicotomía entre la mujer que se construye desde/frente a la mirada masculina, la mujer débil y pasiva (que es potencia de mentira) o la que pretende liberarse y es reactiva (que es potencia de verdad); y ese otro tipo de mujer, la mujer superior, que se autoafirma y constituye por ella misma y en sí misma. Es, precisamente, en esta dicotomía entre la mujer pasiva o reactiva y la mujer afirmativa, como una lucha sin cuartel, dónde algunos autores, como Derrida ( Derrida J., Espolones. Los estilos de Nietzsche, Valencia, Pre-textos, 1997 (2 $2^{a}$ impresión), Elvira Burgos ( Burgos E., en "Afirmando las diferencias. El feminismo de Nietzsche", en Asparkía, XI, 2000, pp. 77-93 o en Dioniso en la Filosofia del joven Nietzsche, Zaragoza, Prensas Universitarias, 1993) o Sarah Kofman (Kofman S., "La question des femmes : une impasse pour les philosophes", en Les Cahiers du Grif, $\mathrm{n}^{\circ} 46$, Paris, 1992;; o Kofman, S., Explosion I. De l'"Ecce Homo" de Nietzsche, Paris, Gallilée, 1992 y Explosion II. Les enfants de Nietzsche, Paris, Gallilée, 1993), han querido ver la semilla de un planteamiento diferente en Nietzsche hasta el punto de identificar en su obra una suerte de hilo que anticipa una especie de feminismo subversivo. Pero independientemente de este tipo de planteamientos que re-visitan las opiniones de Nietzsche -restándoles dureza como una crítica al sistema patriarcal y a su ética de valores masculinos, cristianos y ascéticos, lo cierto es que no se puede olvidar aquí que el hilo conductor que recorre todo su pensamiento, y que va conformándose de distintas maneras a lo largo de toda su obra -como en la urdimbre de un tapiz-es precisamente la voluntad de dominio y su admiración por la fuerza y el poder, y así hay que entender el sentido reactivo de su filosofía. a ser ya el principio de la liberación política femenina; aunque no sólo política, sino también sexual ${ }^{23}$. De modo que, poco a poco se fue aquilatando, en un contexto en el que las nuevas emancipaciones feministas pugnaban por salir, la semilla para una nueva imagen estética de la mujer más degradada, si cabe, porque ahora se apuntalaba no ya sólo sobre la inferioridad, como legado del pensamiento medieval, sino en la injusticia24.

De manera generalizada se prodigan, especialmente en la Francia y Alemania de fin de siglo, personajes femeninos supeditados al amor y al deseo masculinos que contrastan con mujeres libres pero que acarreaban el mal25. En Inglaterra y Francia el romanticismo y el simbolismo improvisan mujeres angelicales confiadas al amor y a la subordinación, que se contraponen con mujeres diabólicas. Se empieza a insistir en la recreación de mujeres peligrosas, codiciosas y asesinas, que recrean los viejos mitos de Salomé o de Clitemnestra que explotan la ginecocracia.

Es fácil deducir que con este tipo de representaciones que vinculaban la mujer a la injusticia, se pretendía proyectar, ni más ni menos, que una concepción social todavía más menospreciativa de las voces que ya pugnaban con fuerza por traspasar los papeles de género definidos por la moral y la cultura patriarcales. Es decir,

23. Véase a Allen, V., The Femme Fatale: Erotic icon, New York, The Whitson Publishing Company, 1983, p. 186.

24“La injusticia es el vicio fundamental de la naturaleza femenina", dirá Schopenhauer (Schopenhauer, A., El amor, las mujeres y la muerte, Op. cit., en www.schopenhauer-web.org $y$ también en Godet., P., La pensée de Schopenhauer, Op. cit., p. 391. Controlar notas y espacios.

25Dottin Orsini, M., La Mujer Fatal (según ellos),Buenos Aires, Ed. La Flor, 1996, pp. 14-19 
se pretendía exorcizar el miedo de una época a la emergencia de los primeros feminismos, que ya se batían por dar paso a una nueva mujer, fuerte e independiente, decidida a entrar definitivamente en la historia. El movimiento de las mujeres sufragistas, como proceso de lucha de las mujeres, ya estaba en liza -desde la declaración de Seneca Falls en la que sería primera convención sobre los derechos de las mujeres en 1848-, y comenzaba a ser el semillero de acciones e ideas del pensamiento feminista que vendría después. Representa, por tanto, no ya el temor masculino hacia lo femenino - una constante en todas las sociedades históricas ${ }^{26}$, sino el horror a lo femenino no explorado y extraño; hacia ese otro femenino que crepita ya con fuerza y empieza a conculcar los límites patriarcales que le habían sido impuestos de manera tradicional. Las Bostonianas ${ }^{27}$, novela escrita en 1886 por Henry James, es también una buena metáfora de los inicios de este

26. Representado en el "horror a su propia contingencia carnal lo que proyecta sobre ella" Beauvoir, S., The Second Sex (Trad. \& ed. Parshley H. M), Knopf, New York, 1993, p. 148. No en vano, la comunión entre la mujer y la naturaleza, donde la naturaleza representa la fertilidad y la reproducción, también es impetuosa y salvaje, o lo que es lo mismo; es peligrosa y animal. En esta visión, que confiere a la mujer los poderes de la naturaleza, reservando al varón el poder de la moral y la inteligencia, la inferioridad de las mujeres pivota tanto en el miedo a su supuesta condición salvaje, como a la necesidad de regular, reprimiendo, el deseo sexual femenino. Cfr., en este sentido, con Dijkstra., B., Op. cit, pp. 259-67

27. Curiosamente Henry James (1846-1916) fue hermano de Alice James (1848-1892), una activista feminista muy reconocida en su tiempo por su lucha para expresarse libremente frente al carácter represivo de la femineidad de la sociedad victoriana. proceso. Al cabo, nada teme más el hombre que ser tocado por lo desconocido.

Desde la Lisistrata de Aristofanes a la Manon Lescaut del Abate Prevost, a la Marquesa de Mertelvil de Laclos (interpretada por Glenn Close en el cine en Amistades Peligrosas), a la Berenice y la Ligeia de Allan Poe, a la Severine de Zola (en La bestia Humana y que el cine también adaptaría en Deseos Humanos), a la Hauteclaire de Barbey d'Aurevill; a la Nora o la Hedda Gabler de Ibsen, a la Laura de Strindberger, a la niña Chole de Valle Inclán, a la Salomé de Oscar Wilde..., a la Vanda de La Venus de las Pieles (y que Polansky también adaptaría para el Cine en 2013), a la Lolita de Navakob..., etc.., $y$ así sucesivamente en una larga lista interminable de títulos, todas influirán en el imaginario cultural y estético de nuestro tiempo mediante la sublimación exagerada de una idea del mal en la mujer que transgrede. La femme fatale, más que un mito estético del feminismo, fue sobre todo un producto masculino del miedo.

\section{El campo de la imagen como espacio de lucha contra la mujer en la "Belle Epoque"}

Así las cosas, cerrando el decimonónico, la guerra contra la mujer se dirime en el campo de la imagen y de las palabras, y no por ello, como bien dice Erika Bornay, fue menos destructiva que muchas gue-

28. El personaje central de una de sus obras más conocidas El padre, que este dramaturgo sueco publicaría en 1887, y ahora destacamos porque en esta obra se basará precisamente uno de los dibujos más conocidos de Kubin: La última nodriza. Un ilustrador que sintetiza perfectamente esta visión exageradamente menospreciativa hacia la mujer. 
rras físicas ${ }^{29}$. Ahora el campo de batalla se dirime en el ámbito de la imagen. La imagen deviene así en el único modo de captar la sensación. Véase sino como se pronuncia el mismo Azorín, por seguir de cerca a nuestras letras, para quien la imagen no es sino la forma "de fijar sobre el lienzo o el papel la sensación": La imagen "es la única realidad, la única fuente de vida y de sabiduría. Y así, este perro joven e ingenuo, que no ha leído a Troyano; este perro sin noción del tiempo, sin sospechas de la inmanencia o trascendencia de la causa primera, es más sabio que Aristóteles, Spinoza y Kant, (....) los tres juntos" 30.

Luego será sobre ella, sobre la imagen, donde se apuntalará la literatura como conciencia crítica de su época, frente a los valores de una sociedad tradicional que comienzan a desvanecerse. La imagen se convierte así en el aliviadero revolucionario donde la creación y el pensamiento comienzan a emanciparse del estado de naturaleza; y la femineidad será la clave de bóveda sobre la que se apuntale el nuevo orden estético. La imagen se auto-celebra así misma en una especie de sortilegio desesperado frente al derrumbadero de los viejos valores sociales; y la mujer será el estereotipo soñado con el que la filosofía y las artes sondearán y explicarán la naturaleza humana, facilitando así una transición entre el mundo de las artes y la vida cotidiana y consolidando una puesta en escena que dispone el lugar desde donde se piensa y se quiere situar a la mujer en el mundo social (en la pasividad o en la injusticia), narrándola así a través de las artes.

Desde la Julia o la nueva Eloísa de Rousseau apurando el XXVIII (y que luego re-

29. Bornay E., Las hijas de Lilith, Ediciones Catedra, Madrid, 2021, p. 69

30. Azorín, Obras completas, Vol. I, Madrid, 1959., p. 920; plicaría en Sofía en El Emilio ..), donde divaga acerca del sometimiento de la mujer a la naturaleza y a las convenciones sociales definidas por los hombres, se evocará a la mujer como un símbolo que imanta y dinamiza a lo masculino; al que hay que hay imitar pero al que también temer ${ }^{31}$. Desde entonces los grandes maestros, Goethe, Balzac, Baudelaire, Strauss, el propio Wagner, Dickens, Flaubert, Wilde, Zola ..., seguirán su camino en sus recreaciones.

El hecho es que, avanzado ya el decimonónico, la literatura se abre a mujeres inéditas hasta entonces. Se abre a la mujer obrera, como la lavandera Gervaise de La Taberna de Zola; a las madres solteras como la Fantine que Victor Hugo recrea en los Miserables o la Germinie Lacerteux de los hermanos Goncourt; o a las prostitutas de vida ligera o criminal como en La Ramera Elisa también de un Goncourt; como también se abrirá a la sublimación dionisíaca o a las expresiones libidinosas del voyeurismo literario ${ }^{32}$ (ahí están Madame Bovary, Janes Eyre, Anna Karenina, Ana Ozores - la protagonista de La Regenta- de Clarín, la flaneuse de Baudelaire

31. Veamos si no como se explaya, en lo que aquí interesa, el propio Rousseau a través de Sain-Preux, en la nueva Eloísa "Mujeres, mujeres -escribe Rousseau- queridos y funestos objetos, que la naturaleza adorna para nuestro suplicio, que castigáis cuando se os desafía, que perseguís cuando se os teme, en las que el odio y el amor son igualmente perniciosos a las que no se puede impunemente buscar ni escapar; ser o quimera inconcebible, abismo de dolores y voluptuosidades; Belleza más terrible para los mortales que el elemento que te ha hecho nacer, desgraciado quien se entrega a tu engañosa calma. Eres tú quién produce las tempestades que atormentan al género humano". Rousseau, J., Julia, o la nueva Eloísa, Madrid, Akal, 2018, p. 157

32. Trigaud, J.M., Persona ou la justice au double visage, Studio Editoriale di Cultura, 1990., p. 254. 
etc); todos ellos son personajes femeninos singulares para su tiempo y que son escrutados por sus autores con temor, porque están ya marcados por una femineidad insólita para la época, que pugna ya con fuerza por salir; personajes con personalidad que, poco a poco, se van desmarcando del arquetipo femenino de su tiempo; hasta llegar a ese otro tipo femenino basado, no ya en la pasividad o en la inferioridad ${ }^{33}$, sino en la injusticia y en el terror, en su sentido mas nietzscheano, esto es, a la Nana de Zola (la primera mujer vamp), que a la postre popularizaría el cine ${ }^{34}$ como la femme fatale y que acabaría siendo un icono en el imaginario estético del siglo XX.

33. Hasta entonces la mujer era representada como doncella, idealizando su fragilidad e inocencia, como en los retratos ensimismados y frágiles de Edward Burne Jones o la Beata Beatrix que representara Dante Gabriel Rosetti. Uno de los pintores y poetas más celebres del simbolismo inglés, que recibió su nombre por ser precisamente el hijo del traductor de la obra de Dante a la lengua inglesa. En sus lienzos representaría perfectamente el ideal de la pasividad femenina. Sus protagonistas serán mujeres espirituales e inocentes, estáticas, con el pelo suelto y que no se comunican. Por ejemplo, la canción de las siete torres (1857) se inspira en la poesía medieval y sus personajes presentan formas arquetípicas. Una mujer canta, melancólica y sin sonreír, refugiada en su mundo interior, mientras un hombre la escucha absorto. Sin embargo, el propio Roset$t i$ tampoco podría sustraerse a esta evolución hacia la mujer fatal, llegando a retratarla mas tarde, utilizando a su esposa y modelo Elizabeth Siddal, como prototipo de aquélla.

34. Acerca de la evolución del concepto de femme fatale, especialmente en el cine, es interesante la obra de Keesey, P., Vamps: An Illustrated History of the Femme Fatale, San Francisco, Cleis Press, 1997; También son muy ilustrativas las páginas de Sánchez Verdejo, F., "Breve análisis de la figura de la femme fatale en el cine", en Orisos. Revista de investigación y divulgación cultural, $\mathrm{n}^{\mathrm{o}}$ 2, 2013, pp. 351-386.
Pero, el rostro de la femme fatale ya se venía representando, mucho antes de que lo hiciera el cine, en la iconografía de la época, hasta el punto de convertirse en el tema de referencia entre las élites artísticas del fin-de-siécle. Ahora sus rasgos van mucho más allá del rostro femenino que representara Flaubert en Madame Bovary o el de Dumas en la Dama de las Camelias o el de Thérèse Desqueyroux de Mauriac. Es tan bello como ellas y tan inteligente como la Janes Eyre de las hermanas Brontë o la Violetta Valéry de la Traviata de Verdi; pero además es malvada, como las mujeres crueles que recogen las escrituras (Eva, Lilith, Dalila y Salomé) o que recrea la propia mitología clásica como Clitemnestra o el pasaje de Filóstrato sobre Menipo y la Empusa acerca del amor frustrado entre un mortal y una mujer sobrenatural ${ }^{35}$; sólo que ahora es más sofisticada y licenciosa, más fetichista y artificial (amante estéril) que desafía a la mujer natural (esposa y madre); se asemeja a los ángeles negros de Baudelaire en las Flores del Mal, una selección de poemas que sería censurada en Francia y publicada en Bélgica, o a las Diabólicas de Jules Barbey d'Aurevilli36.

35. En la Vida de Apolonio de Tiana Filostrato (160-249) narra como una Empusa toma forma humana para seducir a un joven estudiante de filosofía, Menipo. Por suerte, Apolonio se ocupa de desenmascararla a tiempo y ella acaba admitiendo que se dedica a cebar a jóvenes ardientes e ingenuos para, después de relacionarse sexualmente con ellos, apurar su sangre y devorarlos. Ese episodio de la Vida de Apolonio, conocido como la novia de Corinto, inspiró a John Keats, en uno de sus poemas más conocidos: Lamia.

36. La obra quizás más significativa de Jules Barbey d'Aurevill, amigo de Balzac y Baudelaire, e inspirador, entre otros, de León Bloy. Se publicó 1874. Se trata de una obra de seis relatos heterogéneos donde las mujeres asumen el eje de la trama, pero lo hacen como adúlteras o asesinas; 
La mujer fatal será representada en la pintura y lo hará de mil formas por muchos pintores de toda Europa: Jean Delville, Franz von Stuck, Ferdinand Khnopff, Toorop, E. Munch, Gustav Mossa ( Elle, Mary The Magdala, etc). Pero de todos ellos, serían Felicien Rops y el ilustrador austriaco Alfred Kubin los más provocadores, autores de las ilustraciones mas transgresoras de la bohemia noir de la época; la bohême del ocultista Péladan, del vanguardista Mallarmé o el poeta asesino Verlaine ${ }^{37}$. Alfred Kubin representará como pocos esta imagen terrorífica de la mujer en sus ilustraciones. Como en los Caprichos de Goya, aprovechara la imagen de la mujer para relacionarla simbólicamente con la depravación, la muerte y la oscuridad. En unas la presenta como devoradora de su compañero sexual; en Madre Naturaleza (1900), por ejemplo, retrata a una enorme mujer tumbada en el bosque mientras permanece abierta de piernas, ofreciendo su sexo como un lugar oscuro en el que abismarse; o en La Araña (1901), representa a varias parejas copulando sobre una tela de araña mientras una araña enorme extiende sus tentáculos para apoderarse del macho y devorarlo; en otras la representa como un ser sensual, pero lascivo y peligroso como en Astarte en 1913; y en otras la entroniza como un verdugo cruel, como en La dama sobre el caballo (1901), en El día de la matanza (1902) o en El destino del hombre (1903), donde siempre una

duquesas convertidas en vengativas prostitutas. Como llegaría a decir el propio autor: "son historias reales de este tiempo de progreso y civilización tan deliciosas, tan divinas, que, cuando uno se propone describirlas, parece siempre que el Diablo las ha dictado".

37. Con este sobrenombre se le conocería tras disparar a bocajarro dos veces a su amante, el joven poeta Rimbaud. mujer hermosa e imponente ajusticia y da buena cuenta de un puñado de hombres.

Rops irá todavía más lejos, llevará su pintura a unos territorios de provocación insólitos hasta entonces. Ni que decir tiene que su obra fue siempre censurada, y unió fuerzas con otro de los grandes poetas de su tiempo, su amigo Baudelaire. Es suya la portada de Les Épaves (Los naufragios), una selección de poemas de Las flores del mal, que Baudelaire publicaría en 1866, y qué constituye ya toda una metáfora de este feminicidio estético de la mujer ${ }^{38}$. En Rops, las mujeres aparecen junto al Diablo y las prostitutas se convierten en ninfas sagradas, como una metáfora de la toma del poder por parte de la mujer. La mujer que toma el poder deviene así en mercenaria de la oscuridad. La mujer satánica, cuyo eco se retrotrae a la rispidez de los tribunales penales medievales frente a la brujería, ya no recibe el castigo; ahora sencillamente toma el poder. Incluso el mismo Huysmans, el exponente más refinado del decadentismo, y del que hablaremos a continuación, afirmaría que Rops era uno de los artistas más extraordinarios de todos los tiempos al reflejar sobre sus lienzos los supernaturales aspectos de la perversidad; y, en la mayoría de ellos, se situará a la mujer.

\section{El esteticismo decadentista y la femme fatale: la Salomé de Huysmans}

Sería el propio Huysmans en A Rebours (A Contrapelo), la obra que en 1884 en-

38. Basta con reparar en algunos de sus poemas: Las mujeres malditas - Delphine e Hippolyte; la metamorfosis del vampiro, el monstruo, sobre los comienzos de Amna Boschetti, etc...; a los mismos nos remitimos. 
cumbraría al decadentismo ${ }^{39}$, el primero en sintetizar los rasgos que acuñarían el rostro de la femme fatale. Podría decirse que esta obra es la 'Biblia del Decadentismo'. De hecho vino a revolucionar el panorama literario francés. Rompía con el naturalismo de Zola, dando paso al refinamiento y al esnobismo, esto es, a la idea de exquisitez como paroxismo estético. El hedonismo estético, considerado entonces por los jóvenes escritores franceses como decadente (de ahí viene su nombre), se puso de moda, pese al recelo que esta nueva estética, representada en el dandismo de Baudelaire, Verlaine y compañía, despertaba en los círculos literarios oficiales. En esta novela, basada en la figura del conde de Robert de Montesquiou (cuyo retrato al oleo de Giovanni Boldini constituye quizás la metáfora perfecta del dandi de fin de siècle), su protagonista, el duque de Essenties, inspirado en el pesimismo de Schopenhauer, profundamente esteticista y misántropo (en su sentido más nietzscheano), lo conducen a una suerte de cinismo estético, rayano en la extravagancia ${ }^{40}$ flirteando con la perversidad, como reacción ética y estética a las convenciones y el conformismo moral de su tiempo. Acabará recluyéndose en una mansión, en la localidad de Fontenay-

39. Cfr., en este punto a González, Miguel Ángel "Joris Karl Huysmans y su visión de la literatura latina", en Cuadernos de Filología Clásica, Estudios Latinos, 17, 1999, p. 282.

40. La extravagancia decadente le sirve para "escapar de las vulgaridades y del mundo" Huysmans, J. K., A contrapelo, Madrid, Cátedra, 1984, p. 257. Por eso, al igual que Baudelaire, al duque de Esseintes le gustan los libros y los objetos exóticos, las flores raras y enfermas; es sencillamente un sibarita que pudiendo gozar de todos los placeres, se siente hastiado de la vida y necesita experimentar ese sentido oculto de la existencia.
aux-Roses, donde se dedicará a explorar "para el deleite de su espíritu y el placer de sus ojos, obras sugestivas y evocadoras que tuvieran el poder de sumergirle en un mundo desconocido, de aportarle revelaciones ocultas, de estremecerle el sistema nervioso mediante eruditas histerias"41; y a buen seguro que lo hará, especialmente de la mano de Baudelaire y de Gustave Moreau.

$Y$ es que es en Baudelaire, a quien ya nos hemos referido, el exponente más refinado del dandismo hasta entonces, en quién más se inspirara el duque en su búsqueda de la belleza. El propio Baudelaire dirá de sí mismo (en el Pintor de la vida moderna) "en verdad que no me equivocaba al considerar el dandismo como una especie de religión" ${ }^{42}$. Las flores exóticas que, por ejemplo, el duque de Essenties, manda traer desde el mismo Chatillon son un reflejo de sí mismo. Son flores extrañas y de apariencia enfermiza, un guiño callado a las Flores del Mal, a las que Huysmans describe, precisamente, como "flores carcomidas por la sífilis y la lepra, que mostraban una carne lívida, amoratada por la roséola, o adamascada por los herpes"43. El dandismo deviene así en una suerte de religión donde prevalece el "diablo meridiano", el demonio del mediodía, asociado desde Atanasio de Alejandría y Juan Casiano, en su obra de Instituta Coenobiorum, con el aburrimiento y la tristeza (evagatio mentis) en las horas del mediodía, esto es, con la acedia medieval que asolaba el descanso del monje medieval. De la misma forma que la fantasía y el "deseo eran para el clérigo y el monje me-

\section{Ibid, p. 176.}

42. Baudelaire, Blazac, Barbey D'Aurevilly, El dandismo, Barcelona, Anagrama, p. 109.

43. Huysmans, op. cit., p. 218. 
dievales la batalla cotidiana de su melancolía", que desaguaba en "deliciosas imágenes de placer inasequibles"44, la acedía encumbrará a Charles Baudelaire, sobre todo en Las flores del mal, dónde el propio autor situará a la poesía bajo la égida de la acedia. "Con el decadentismo la figura del Dandi constituye de algún modo una reencarnación del monje acidioso" 45 .

Pero será con Huysmans cuando la adoración esteticista, en su versión más decadente, trastoca el paso a las letras francesas, convirtiendo a partir de entonces la extravagancia y el paroxismo estético en una suerte de misticismo que subvierte el orden; pero esta especie de religión, donde Baudelaire ocupa el lugar de Jesucristo (serán sus poemas el misal que ocupe el altar) y donde el duque Des Esseintes oficia de sacerdote, no es para todos; sólo lo es sólo para unos pocos escogidos, para los espíritus más refinados y sensibles capaces de fiar la existencia al poder demiúrgico del arte. "Había mandado habilitar un gran salón destinado a recibir a sus proveedores. Estos iban entrando, se instalaban uno junto a otro en una hilera de sillas de coro de iglesia, y entonces él subía a un púlpito magistral y les predicaba un sermón sobre el dandismo" ${ }^{46}$.

Ahora el mal produce el bien y lo hace a través del arte. Se pergeña así la figura aristocrática del Genio, que será varón y artista o esteta y profundamente sofisticado, pero también misógino. Ahora el

44. Gurmendez C., La melancolía, Madrid, Espasa Calpe, 1994, p. 46.

45. Salas, $\mathrm{M}^{\mathrm{a}} \mathrm{C}$., El afecto sin objeto y la escritura fragmentaria. Una lectura del desasosiego pessoano. Madrid, Universidad Autónoma de Madrid, 2006, p. 148). Cfr, también con Segura, A., La acedia y el decadentismo fine-secular de Huysmans, en EPOS, XXXIV, 2018, pp. 303-309. 46. Huysmans, Op. cit., p. 130. acidioso, el genio, de la misma forma que se escapaba de la realidad por medio de la pereza y la fantasía, buscando el placer en la extravagancia o en imágenes prohibidas, también repudiará a la mujer, como también antes lo hacía el monje acidioso. Al duque des Esseintes le ocurre exactamente igual, gracias a la sugestión que le proporciona el arte extravagante puede escapar a cualquier lugar, tanto lícito como ilícito y como los monjes "una vez más se sentía obsesionado no por la religión misma, sino por la malicia de los actos libertinos y de los pecados que ella condena"47. Si para el artista antes la mujer participaba en la creación a través de la inspiración; ahora deja de ser una musa; ahora castra y trivializa al artista, en la búsqueda de Emerge así uno de los temas más recurrentes en la bohemia artística del principios de siglo: el "genio castrado", y que devendrá decisivo en el feminicidio estético del que aquí hablamos.

Es precisamente, a cuenta de uno de los cuadros de Moreau, el de Salomé, donde se atisba una de las primeras descripciones literarias de este arquetipo femenino. El cuadro de Moreau cautivará al Duque de Essenties, que pasará horas enteras recreándose en él, en “(...) Salomé, que tanta fascinación ha ejercido sobre los artistas y los poetas, obsesionaba desde hacía años a Des Esseintes. ¡Cuántas veces había leído en la vieja Biblia de Pierre Variquet, traducida por los doctores en teología de la Universidad de Lovaina, el Evangelio de San Mateo que cuenta, con ingenuas y breves frases, la degollación del Precursor"48. Ahora la describe con los rasgos propios de la que será la femme fatale. Dice así “ (...) no era ya solamente

\section{Ibid., 231}

48. Ibid., p. 178. 
la bailarina que con una torsión corrompida de sus riñones arranca un anciano un grito de deseo y un aviso de erección que rompe la energía y disuelve la voluntad de un rey con meneos de senos, sacudidas de vientre y estremecimientos de muslos; en cierto modo se volvía la deidad simbólica de la indestructible Lujuria, la diosa de la inmortal Histeria, la Belleza maldita elegida entre todas por la catalepsia que le envaró las carnes y le endureció los muslos; la bestia monstruosa, indiferente, irresponsable, insensible, que envenena, lo mismo que la Helena antigua, cuanto se aproxima a ella, cuando la ve, cuando la toca"49.

Así las cosas, la Salomé (de Petrino, de Tiziano, de Caravaggio, de Rubens, etc), la Judith de Jan Sanders o de Jan Massys, dan paso ahora a un tipo de femineidad mucho más hechizante, oscura y cruel: a la Beatrix de Balzac (contrapunto de la Beatriz angelical de Dante), a la Carmen de Merimée, a la Salomé de Gustave Moreau, de Gustav Mossa o Henri Regnault, si hablamos de lienzos; o a la de Oscar Wilde si lo hacemos de teatro ${ }^{50}$ (que destacaría también por las ilustraciones que Aubrey Beardsley incluyó en la obra) $)^{51} \mathrm{o}$ a

\section{Ibidem}

50. Una Salomé muy diferente, más refinada y excitante, pero también más cruel, conforme a los postulados estéticos que ya se abrían paso en la literatura gótica, de ascendencia decadentista y simbolista, y que parece haberse inspirado en las Herodías de Flaubert. Quizás por eso el autor irlandés optó por publicarla originariamente en francés en 1893, en París y a cargo de la Librairie de l'Art Indépendant y dedicada al escritor Pierre Louÿs. Se traduciría al ingles un año más tarde, en febrero de 1894, por lord Alfred Douglas, a quien le dedicó la versión inglesa.

51. No en vano, fue uno de los exponentes artísticos del decadentismo inglés. Amante de lo grotesco, representa perfectamente el estado espiritual de la época. Su estilo modernista, cínico la de Rubén Darío si lo hacemos de poesía ${ }^{52}$; a la Hécate de Pierre Jean Jouve ${ }^{53}$; a la Mujer sin sombra de Strauss sobre el libreto de Hugo Von Hofmannsthal y que este último novelaría en 1919; o la Lulú que popularizaría Frank Wedekind en El espíritu de la tierra y La caja de Pandora, precisamente las obras por las que se recordará a este escritor y bohemio alemán.

y satírico, dio lugar a una obra artística estéticamente rupturista e hipnótica. Cuando se publicó Salomé en febrero de 1893, Beardsley realizó un dibujo (J'ai Baisé Ta Bouche, Jokanaan) para el número de abril de revista de arte The Studio. A raíz del mismo Wilde le encargaría todas las ilustraciones para la versión inglesa. Las ilustraciones ya anuncian los rasgos mórbidos y eróticos, que con el tiempo configurarían estéticamente el estereotipo femenino. Unas ilustraciones que John Lane, el editor de la edición inglesa, publicaría nuevamente, pero esta vez sin censuras, en 1907 bajo el título "A Portfolio of Aubrey Beardsley's drawings illustrating "Salome" by Oscar Wilde". Las 16 ilustraciones pueden consultarse en el siguiente enlace: https:// www.bl.uk/collection-items/aubrey-beardsleyillustrations-for-salome-by-oscar-wilde\#

52. Donde el nicaragüense insiste más que en ninguno de sus poemas en esta idea mortífera de la potencia femenina. En la serie "Otros Poemas, poema XXIII (1910), sería todavía más explícito que en el relato de Onfalia y Hércules que elucida como pocos esta visión que relaciona femineidad y muerte: "En el país de las Alegorías Salomél siempre danzante Herodes eternamentel y la cabeza de Juan el Bautistal ante quien tiemblan los leones./Cae al hachazo, sangre llueve/ pues la rosa sexual al entreabrirse/conmueve todo lo que existe/con su efluvio carnal/y con su enigma espiritual".

53. Hécate.., Aventure de Catherine es una de las obras más interesantes de Pierre Jean Jouve y puede leerse como una poderosa crónica de la vida en los círculos intelectuales, sociales, artísticos y feministas de la Europa de los años veinte. En ella, el personaje protagonista, Catherine, al igual que Hécate, la diosa lunar con la que se la compara, lleva a la muerte a todos los que ama. 


\section{El drama de Lulú como moraleja frente a la mujer nueva}

Es en El espíritu de la Tierra (1895) donde nacerá el arquetipo de Lulú. Luego vendrá La Caja de Pandora (1904), donde Lulú regresa a la marginalidad y sucumbe. En cualquier caso, en ambas novelas se sublima la sensualidad y el erotismo como elementos propios de la femineidad natural, que no se compadecen con la sociedad burguesa, moralista, patriarcal y profundamente restrictiva, pero donde la sexualidad - con represión o sin ellaocupaba un papel relevante, como lo explicaría la emergencia por aquél entonces del psicoanálisis. Sin embargo, el personaje de Lulú será diferente a la representación finisecular de la femme fatale. Quizás, por eso, ha sobrevivido a lo largo del tiempo, siendo muchas sus adaptaciones. Es un personaje, si se quiere, más complejo; representa el poder de la feminidad salvaje, amoral -que no inmoral como se comenzaba a representar a la mujer vamp-y, hasta cierto punto, pasiva, como un vestigio callado de la vieja femineidad, de la dolce far niente, pero que, al tiempo, sigue siendo letal al poseer la capacidad de destruir a los hombres que se acercan a ella. Si en el Espíritu de la Tierra se describe el ascenso de Lulú, en La caja de Pandora se narra su caída. Condenada por el asesinato de su marido consigue escapar, recalando en el siniestro Londres victoriano donde ejercerá la prostitución y vivirá en la marginalidad, sin belleza y ya sin cautivar, hasta el momento de su muerte en noche buena y a manos de Jack el Destripador.

El drama de Lulú representa la hipocresía de la moral burguesa, incapaz de com- prender la fuerza de la naturaleza. Lulú representa, ni más ni menos, que la inadaptación de la mujer en una sociedad que ya no es la suya; una sociedad que no transige con sus procesos de lucha en pos de su independencia política, y que ya estaban en liza a través del movimientos sufragistas y su política sexual feminista ${ }^{54}$. Su muerte a manos de Jack el Destripador, un respetable burgués que esconde al asesino sexual ${ }^{55}$, es toda una metáfora de hasta qué punto las élites intelectuales y artísticas de la época se resistían a admitir la irrupción de la mujer en los nuevos espacios sociales; hasta el punto de llegar a considerar el asesinato como mecanismo de control de su acceso a unos espacios que tradicionalmente le habían sido prohibidos. Esta es su moraleja ${ }^{56}$.

Hay que decir que el asesinato sexual de la mujer fue un recurso habitual entre los temas de la bohemia literaria y artística de la época, llegando a ocupar un lugar central en la obra de no pocos autores expresionistas, especialmente en el aventajado expresionismo alemán ${ }^{57}$, en un período en el que el seguimiento mediático de los crímenes sexuales estaba de moda. Oscar Kokoschka, por ejemplo, escribirá en 1909 la que sería considerada con el

54. Walkowitz, J., La ciudad de las pasiones terribles. Narraciones sobre el peligro sexual en el Londres victoriano, Ediciones Cátedra, Madrid, 1999.

55. Al más puro estilo del personaje ambivalente Jekyl1/Hyde (1886), la obra de Robert Stevenson, que se estrenaría poco antes del primer asesinato de Jack, y del que parece su encarnación.

56. Pérez Díaz, P \& Gil Díaz, C., "Los rostros de Lulú" en El Genio Maligno. Revista de Humanidades y Ciencias Sociales, no 18, 2016, pp. 1-11. 57. Véase por ejemplo a Tatar, M., Lustmord. Sexual Murder in Weimar Germany, Princeton University Press, Princeton, New Jersey, 1995 
tiempo la primera obra del expresionismo teatral alemán. Se titulaba, nada más y nada menos, que El asesino, la esperanza de las mujeres. Una pieza teatral, basada en la obra misógina de Otto Weininger titulada Sexo y Carácter (1903). El cartel del estreno de la misma es tan explícito que huelgan las palabras ${ }^{58}$.

La difusión periodística de los asesinatos sexuales, especialmente los de Jack el Destripador y Landrú, despertó una especie de grotesca fascinación entre el público burgués de la época, al que no se sustrajeron las élites intelectuales y artísticas que vinieron a apuntalar, a través de sus creaciones, el mito del que habrá de ser el lustmörder por excelencia: Jack el destripador. Jack sintetiza míticamente a todos los asesinos en serie; sea cual fuere su tiempo o lugar, desde Gilles de Rais al carnicero de Milwaukee; todos ellos, ya fueran reales o personajes de ficción, se condensan dentro de su leyenda. Jack el destripador, el asesino en serie del barrio londinense de Whitechapelm, deviene así, merced a la literatura y al teatro finisecular y más tarde del expresionismo alemán, en el paradigma del asesino sexual, al que imitaran los "lustmörder de Weimar, los

58. El eje de la trama es la lucha de los sexos... en un entorno mítico, donde se pretende desmenuzar la idea de mujer. El varón como ser puro y espiritual se supedita a los deseos de la mujer, como ser falso y parasitario, al más puro estilo schopenhaueriano y nietzschano. El drama deviene así en una alegoría del acto sexual, con su carga de dominación. Mientras el varón intenta escapar, ella no ceja, siendo su única esperanza, la aniquilación. Años más tarde, en 1919, Hindemith (compositor expresionista alemán polifacético) la llevaría a la ópera, estrenándola en 1921 junto a su otra ópera Das Nusch-Nuschien (la segunda de su trilogía expresionista) en Stuttgart, dónde causó un escandalo merced al tratamiento explícito que hizo de la sexualidad. psychokiller americanos y los psicópatas asesinos sexuales de cualquier nacionalidad y época"59. Ni que decir tiene aquí que el enigma de la identidad de Jack -la prensa victoriana de la época se estremecía con la sofisticación grotesca de sus crímenes, pero se los atribuía a judíos o a carniceros- puede y debe relacionarse con la pujanza ya entonces del movimiento sufragista. Representa no ya la ambivalencia del hombre victoriano entre el deseo sexual y el miedo a la mujer. Representa mucho más: representa el odio masculino hacia la mujer.

No han sido pocas las reapariciones del personaje de Lulú; de hecho podría decirse que es de los pocos retratos de mujer fatal que se han mantenido intactos, pese a sus numerosas recreaciones a través del cine, la música y la literatura. Entre las más interesantes destacan especialmente su adaptación al cine de La Caja de Pandora, en 1928, de Georg W. Pabst, que pasará a la historia del cine por ser la primera en abordar el tratamiento abierto de la sexualidad, introduciendo por vez primera la aparición del lesbianismo en la pantalla60; la ópera de Alban Berg, cuyo libreto, de una bellísima factura y

59. (...) seres que buscan la satisfacción sexual a través de la satisfacción de la pulsión de la muerte. (...) es el otro monstruoso, el oculto el transgresor...)"Santamaría Blasco, L., Santamaría Blasco, L., "Asesinos victorianos en la República de Weimar. De Psicho Killers y femme fatales, en Herejía y Belleza. Revista de estudios culturales sobre el movimiento gótico, $\mathrm{n}^{\circ} 2,2014, \mathrm{p} .40$.

60. Pero no sería la ultima de Pabst en este sentido; poco después rodaría el drama Tres páginas de un diario (1929), otra obra maestra del cine mudo, Prix de Beaute en 1930. Las tres películas fueron severamente censuradas debido a su marcado contenido sexual y a la conmoción que suscitaba el tratamiento abierto de la sexualidad, amén de su fuerte crítica social. La censura y la 
compuesto en dos actos, se estrenaría de manera póstuma, el 2 de junio de 1937 en Zúrich; o la versión de Ángela Carter -también de edición póstuma ${ }^{61}$-, que fascinada desde su juventud por el personaje de Wedekind -especialmente por el papel que hiciera Louise Brooks ${ }^{62}$ en la película de Pabst- en detrimento de la mismísima Marlene Dietrich-, realizó una adaptación en clave "intersexual" -al cabo no dejaba ser la primera traducción feminista de la obra de Wedekind-, que relee y reescribe sus páginas, pero esta vez desde la mirada de las mujeres. Lulú, deja de ser ahora un monstruo -a ojos de un pornógrafo como se jactaba el propio Wedekind-, para convertirse en una heroína.

Que fuera Alban Berg quien llevara a la ópera la obra de Wedekind, no es tampoco casual. Berg será el precursor, junto a Schönberg, del dodecafonismo; un movimiento estético que fue para la música, lo que el expresionismo fue para la pintura o el verismo italiano y el realismo para la literatura. Es verdad que el dodecafonismo supuso entonces una ruptura del modelo tonal tradicional al introducir la disonancia en el repertorio musical; pero

irrupción del cine sonoro acabaron apagando su potencial frente al gran público.

61. Carter A., The Curious Room. Plays, Film Script and Opera, Londres, Chatto \& Windus, 1996.

62. La Caja de Pandora película convirtió a Louise Brooks en un mito, convirtiéndose así en el rostro femenino más icónico del cine mudo. Con su corte de pelo y sus vestidos cortos, llegará a ser todo un icono para la moda, encarnando a las 'flapper' de los años 20, esas jóvenes emancipadas que sobrecogieron a la puritana sociedad estadounidense. Valentina, la primera heroína del Comic, que creara el ilustrador italiano Guido Crepax, se inspiraría en ella. Un personaje poderoso, de una fuerte sensualidad y huérfano de moralismos e hipocresías. representaba mucho más que una simple transformación estética; su nueva sensibilidad estética era el reflejo del asalto a la razón, a la jaula de hierro de Weber, por parte de la sociedad europea de postguerra, sobre todo en la Alemania de Weimar. Con Berg la música deja de ser inofensiva y comienza a hacerse eco de los procesos sociales en un momento en el que la sociedad europea se abismaba entre las secuelas de la primera guerra mundial y el anuncio de la siguiente. Si Schönberg inauguró este nuevo modelo tonal, fue Berg quien le dio sentido, dando entrada en sus composiciones a los temblores de toda una generación que había visto como Europa se asomaba de manera implacable al derrumbadero. De la mano de Berg el conflicto social irrumpe por fin en la música ${ }^{63}$. Ahora la ópera dejará de ser una experiencia estética de clase, tradicionalmente reservada a una minoría elitista; ahora.., la ópera deja de ser wagneriana y se sincroniza con el aliviadero general de la cultura ante el caos de la guerra, por medio de no pocos movimientos estéticos como el dadaísmo -y su profundo sentido antiartístico y antipoético-, el expresionismo, el verismo.., etc.

Desde esta perspectiva, no es de extrañar que Berg se interesara desde el principio por el personaje de Lulú; ya en 1905, mucho antes de su estreno, asistió a la primera representación de la Caja de Pandora en un contexto donde la sociedad europea titubeaba, pero donde la sexualidad empezaba ya a ocupar un papel decisivo. Desde entonces el personaje de Lulú se

63. Muñoz, B., "Dodecafonismo y Sociedad de entreguerras. El reflejo del conflicto social en el Wozzeek de Alban Berg", en Revista española de investigaciones sociológicas (REIS), $\mathrm{n}^{\circ}$ 84/98, $\mathrm{p}$. 269. 
instalará en el imaginario europeo como el arquetipo de femme fatale definitivo.

En fin, Lulú representa a la mujer como autora de una violencia imperceptible que aniquila al hombre en su afán por alcanzarla, como la Hipólita Sanzio de Gabrielle d'Annunzio en El triunfo de la muerte ${ }^{64}$. Representa el eros mortal, frente a la madre abnegada y ángel del hogar (representada, por ejemplo, en la figura poderosa de Gertrudis, la protagonista que ensalzara Unamuno en la Tía Tula, como contrapunto a la femme fatale) $)^{65}$, que subyuga al hombre y lo conduce, a través

64. El triunfo de la muerte (1894) de Gabriele D'Annunzio condensa la metáfora de la transición de la que aquí hablamos; al igual que buena parte de la bohemia literaria de la época, quería crear (y quizás también de sobrevivir a través de él) un personaje que representara la visión nietzscheana de la vida superior, del hombre superior; de hecho la novela se abre con un exergo que contiene un pasaje de Más allá del bien y el mal de Nietzsche. Recrea la vida de un hombre libre de cualquier moral que vive cautivado por el arte y la belleza y que se define enérgico, heroico y dominante; pero un personaje que se va forjando en contraposición y en detrimento de su alter ego femenino. Es una novela de sensibilidad mórbida que narra la pasión claustrofóbica entre Giorgio Aurispa (un héroe decadente e introspectivo como contrapunto al buen burgués: inepto y esteta, pero sin perspectivas para el que la realidad humana resulta desesperada e inútil) e Ippolita Sanzio (Hipólita). La intensidad del deseo y su dependencia obsesiva hacen brotar en Giorgio un odio instintivo, hasta el punto de fantasear en secreto con destruirla para liberarse de la influencia del ídolo.

65. La tía Tula es una mujer individualista e inteligente, de carácter recio y muy superior a los hombres que la rodean, a los que Unamuno presenta como zánganos; tiene una enorme sensualidad, pero es piadosa y ejemplar en el cuidado de los suyos, en este caso de sus sobrinos, por quienes se sacrifica hasta el punto de renunciar al amor de su vida, su cuñado Ramiro. de la belleza y el amor que le inspira, al abismo.

La mujer ahora tiene el poder de subyugar, pero lo hace dialogando silenciosamente con las sombras. Ahora es la mujer la que, al emanciparse, contrae la muerte o la perdición, pero no para ella, el poema gótico The Vampire de Rudyard Kipling ${ }^{66}$, o el poema La Belle Dame sans Merci (la mujer bella sin piedad $)^{67}$, escrito prácticamente un siglo antes, en 1819, por uno de los poetas más representativos del

66. Que escribiría en 1897 y que acompañaría al lienzo de Philip Burne-Jones del mismo año y título. Uno de los lienzos que mejor evocan el vampirismo de la mujer con poder. Si bien sería con Alfred Kubin, más conocido como ilustrador que como escritor, con quien el vampirismo femenino sobre un lienzo alcanzaría su máxima expresión. En La vampira II (1940), representa a la mujer convertida en animal sanguinario después de chupar la sangre de su amante hasta la extenuación para seguir viviendo; las mujeres se nutren del flujo vital del hombre. Poco antes, en 1935, representaría otra escena en la que una mujer mirándose en el espejo queda completamente trastocada al reparar cómo su sexo se ha sido reconvertido en ese mortífero animal.

67. Este poema que se inspira en el título de un poema cortesano francés del poeta Alain Chartier, recrea el diálogo entre el poeta y un triste caballero anónimo. Éste último le cuenta a Keats el motivo de su aflicción: su encuentro en el bosque con una hermosa mujer. El caballero errante la sube a lomos de su caballo y ella lo guía hasta una gruta perdida. Allí se aman hasta que sucumbe, entre besos y caricias, a un profundo sueño. Y mientras lo hace, sueña con un enjambre de antiguos reyes, príncipes y guerreros; otrora hombres poderosos, pero que ahora palidecen y que le previenen del peligro, pues ellos han sido ya esclavizados por la dama sin piedad. Esa mujer tierna y poderosa capaz de supeditar a reyes no es otra que la belle dame sans merci, que atesora el inmenso poder de inspirar amor, pero cuando lo ejerce lo hace para conducir a los hombres más poderosos a la esclavitud. 
romanticismo ingles: John Keats y que es ya, de suyo, todo un anuncio de esa imagen de la mujer independiente que lo quiere todo y que abisma a quienes se acercan a ella; que se proyectará después sobre el imaginario, entronizándola como la única alternativa posible para la mujer con poder.

La muerte o el abismo, por tanto, representan aquí que el poder culminante ejercido por una mujer, tiene sólo un fin: su propia realización individual, pero a costa de la vida del otro al que sacrifica; en ella ya no hay ya abnegación. Este podría ser el punto extremo y culminante de un poder sobrenatural, que ahora sintetiza la belleza y las cualidades que tradicionalmente el patriarcado había reservado a lo masculino. Lulú es tan inteligente y poderosa como el mejor de los varones, pero es en su belleza y sexualidad, hechizante y fría, donde radica la fuente de su poder ${ }^{68}$; un poder que va asociado ahora a la ruptura de los limites estables y aceptados, que les han sido dados (Schopenhauer) merced a su relación armoniosa con el hombre. Por eso es subversivo. Desde esta mirada, que acabaría colonizando el imaginario, la independencia de una mujer será subversiva o no será69.

Ni que decir tiene que la caracterización de este tipo de mujer que subvierte y cau-

68. Ahora la mujer es la "diosa de la carne, ... la reina del pecado". Campbell, J., The Hero with a Thousand Faces. Princeton, Princeton U. P. , 1976., p. 123.

69. Y es que este tipo de mujer independiente, que se aleja de la maternidad y que utiliza su sexualidad como reclamo para sus objetivos, es mala madre, seduce, juega y asesina como en los personajes que recreó antes Gautier en La morte Amoureuse (1836) y en Une Nuit de Cléopatre (1845) o Flaubert en Salambó (1862), y como representará más tarde el cine. sa la muerte representa el miedo de una época a la irrupción de un nuevo tipo de femineidad, que comenzaba ya a dibujarse en un contexto en el que ya pugnaban con fuerza los primeros movimientos feministas, que reflejan ya el sentido del cambio de la mujer moderna; desde la primera fleneuse ${ }^{70}$-la primera mujer paseante sola que narrara Baudelaire-, con sus cambios de apariencia y sus formas de estar, a la mujer sexualmente libre, más independiente y menos maternal ${ }^{71}$.

70. Un poema titulado "À une passante" (A la que pasa), uno de sus poemas más bellos añadidos a la segunda edición de Las flores del mal (1861). Téngase en cuenta, que la flânerie, más allá del acto en sí mismo de callejear entre la multitud de la ciudad decimonónica, representa, como vino a elucidar Walter Benjamin, en el segundo capítulo de El París del Segundo Imperio según Baudelaire titulado "El flâneur", una experiencia mucho más completa relacionada con el placer onanista de ver y sentir anónimamente. La pluma de Poe, Balzac, Baudelaire o Wilhelm Jensen serán un buen ejemplo. El personaje de Gradiva, por ejemplo, que escribiría Jensen en 1903 es una buena metáfora de lo que aquí decimos, de esas flâneuses que han sido subsumidas u ocultadas. En ella relata la historia de Norberto Hanold, un joven arqueólogo alemán que se obsesiona con la imagen de una mujer que aparece en un relieve clásico. Se queda fascinado por su majestuosa forma de caminar: mientras el pie izquierdo avanza apoyándose totalmente en el suelo, el pie derecho permanece erguido en un gesto perfecto. La flâneuse también se proyecta en el imaginario estético y literario modernos como un modelo de visualidad androcéntrica, en un contexto donde la mujer moderna comenzaba a ocupar las calles de las ciudades.

71. La asociación de lo femenino con la esterilidad, como en La Mujer sin Sombra de Strauss y Hofmannsthal, es típica del arte fine secular, que ensalza la esterilidad pero no ya sólo como un signo de la liberación sexual en la mujer, sino como la clave sobre la que pivota la idea de progreso. La organización técnica del mundo de la modernidad contrae la eliminación de la fertilidad, 
Y lo hace a modo de advertencia, por una parte, recreando (estéticamente) los riesgos que contrae la independencia de la mujer, que se sintetizan en la femme fatale y en la injusticia que apareja, una injusticia que deviene trágica y que ejerce desde su libertad sexual pero, por otra, invirtiendo el esquema; ahora es ella quien procura el castigo, y es el varón, que la ha sometido monopolizándola y humanizándola a su manera, el que lo recibe.

Con Lulú se abre un nuevo tipo de mujer, de actitud libre e independiente, pero peligrosa y reprochable, que compartirá el imaginario estético del siglo XX junto a la femme fragile, ocupando en él también un lugar. A partir de entonces, ambos modelos perduraran hasta nuestros días, coexistiendo en la memoria común, en los subconscientes colectivos, incluso hasta

como vínculo con la naturaleza. Esta es quizás la moraleja de la Mujer sin Sombra de Strauss - (y que se condensa en la figura de la emperatriz). He aquí la contraposición entre el Eros y el Ethos, entre el placer como ausencia de vida y el deber ser representado en una ética de la femineidad basada en la maternidad. La "nueva mujer" se relaciona así con la "transición demográfica" que aparejaba la modernidad, con índices de nacimientos más bajos y tasas de mortalidad más bajas. La liberación femenina deviene, por tanto, en "un problema", no ya en términos políticos y económicos, sino en términos reproductivos de la vida humana. La belleza del lienzo de Giovanni Segantini titulado Las malas Madres que vería la luz en 1886 y por el que ingresaría en el circulo más exclusivo del simbolismo europeo, es la viva metáfora de lo que aquí decimos. Se inspiraría en un poema de Luigi Illica, uno de los libretistas de Giacomo Puccini. Representa el progreso de las madres culpables de negligencia infantil (o algo peor) a través de un purgatorio budista representado por el valle frío, lúgubre y sin hojas en primer plano. Después de pagar así por sus pecados, finalmente alcanzan el Nirvana, un paraíso budista, representado por la lejana cadena montañosa, inspirada en los Alpes suizos. en los sobreentendidos de cada generación. Pocas mujeres han podido sustraerse a ese esquema binario de dominio que o las esconde o las supedita -a través del miedo- al relacionar sus anhelos de independencia moral y sexual con el peligro o la injusticia. Este modelo se desplegará más allá del plano estético y formal hasta llegar a colonizar éticamente el ámbito de la praxis; irrumpiendo en los lugares donde las mujeres viven y se desarrollan como sujetos, disponiendo en qué lugar debe situarse cada una, de tal suerte que ninguna podrá ocupar otro simultáneamente, siendo ese y sólo ese el lugar que ocupe; pues los hombres, como ha señalado Deborah Cameron, sólo pueden ser hombres si las mujeres pueden ser mujeres sin ningún tipo de ambigüedad, es decir, si estas los sitúan o los excluyen del centro de sus vidas ${ }^{72}$.

\section{Bibliografía}

Allen, V., The Femme Fatale: Erotic icon, New York, The Whitson Publishing Company, 1983.

Azorín, A., Obras completas, Vol. I, Madrid, 1959.

Aviñoa, X., Introducción a Goyescas. Integral para Piano/ Enrique Granados, Goyescas 2, vol. 4, Barcelona, Ed., Musica Boileau, 2001

Baroja P., "Divagaciones apasionadas", en Obras completas, Madrid, Biblioteca Nueva, 1946.

Beauvoir, S., The Second Sex (Trad. \& ed. Parshley H. M), New York, Knopf, 1993.

72. Véase a Cameron, D., Feminism and Linguistic Theory, London, Macmillan, 1985. 
Boaventura, S., Crítica de la razón indolente, Bilbao, Desclée de Brouwer, 2003.

Baudelaire, Blazac, Barbey D’Aurevilly, El dandismo, Barcelona, Anagrama, p. 109.

Burgos E., Dioniso en la Filosofía del joven Nietzsche, Zaragoza, Prensas Universitarias, 1993.

Burgos E., en "Afirmando las diferencias. El feminismo de Nietzsche", en Asparkía, XI, 2000.

Cameron, D., Feminism and Linguistic Theory, London, Macmillan, 1985

Campbell, J., The Hero with a Thousand Faces. Princeton, Princeton U. P. , 1976.

Carrasco N., "La ciudad enferma de Glaucón. El problema de la pleonexia en Platón", en Grau A., Actes del Primer Congrés Catalá de Filosofía, Institut d’Estudis Catalans \& Societat Catalana di Filosofia, 2011

Entzminger B., The Belle Gane Bad, Louisiana, Louisiana State U.P., 2002.

Derrida J., Espolones. Los estilos de Nietzsche, Valencia, Pre-textos, 1997.

Dijkstra., B., Dols of Perversity: Fantasies of Feminine Evil in Fin de Siecle Culture, Oxford., O. U. P. 1986.

Dottin Orsini, M., La Mujer Fatal (según ellos), Buenos Aires, Ed. La Flor, 1996, pp. 14-19

Duby, G., y Perrot M., "Escribir la historia de las mujeres", en Historia de las mujeres, Barcelona, Circulo de Lectores, 1994

Gilbert, S., y Gubar, S., The Madwoman in the Attic: The Woman Writer and the Nineteenth-Century Literary Imagination, New Haven, Yale U. P, 1984

Golden, E., Vamp: The Rise and Fall of Theda Bara, New York, Emprise Publishing, 1996.
González, M.A., "Joris Karl Huysmans y su visión de la literatura latina", en Cuadernos de Filología Clásica, Estudios Latinos, 17, 1999.

Grosz, E., "Bodies and Knowledges: Feminism and the Crisis of Reason", en Alcoff, L \& Potter, E., (eds.), Feminist Epistemologies, New York, Routledge, 1993.

Heilbrun, C.G., Writing a Woman Life, New York, Ballantine Books, 1988.

Higashi, S., Virgins, Vamps and Flappers: The American Silent Movie Heroine, Montreal, Eden Press Women's Publications Inc., 1978.

Huysmans, J. K., A contrapelo, Madrid, Cátedra, 1984, p. 257.

Keesey, P., Vamps: An Illustrated History of the Femme Fatale, San Francisco, Cleis Press, 1997.

Kofman, S. "La question des femmes: une impasse pour les philosophes", en Les Cahiers du Grif, n46, Paris, 1992.

Kofman, S., Explosion I. De l"Ecce Homo" de Nietzsche, Paris, Gallilée, 1992

Kofman, S., Explosion II. Les enfants de Nietzsche, Paris, Gallilée, 1993

Maeztu., R., Hacia otra España, Madrid, Ediciones Rialp, 1967.

Moratin, L.F., El sí de las niñas, Madrid, Cátedra, 1978.

Nietzsche, F., Ainsi parlait Zarathoustra, Paris, Librairie Genérale Française, 1983.

Nietzsche, F., El ócaso de los ídolos, Madrid, Ediciones BUSMA, 1985

Nietzsche, F. Masculin, féminin. Présentation et choix de textes de Didier Raymond, Paris, Editions du Rocher, 1990. 
Nietzsche, F., La Gaya Ciencia. Puede consultarse en abierto en https://www. guao.org/sites/default/files/biblioteca/ La\%20gaya\%20ciencia\%20.pdf.

Nietzsche, F., Más allá del bien y del mal, Alianza Editorial, 2012. Versión Kindle

Pérez Díaz, P \& Gil Díaz, C., "Los rostros de Lulú" en El Genio Maligno. Revista de Humanidades y Ciencias Sociales, $n^{\circ} 18$, 2016.

Rojas Parma, L., "Lo femenino detrás del poder: Aspasia de Mileto", en Cuadernos UCAB, n 7, 2009.

Salas, $\mathrm{M}^{\mathrm{a}} \mathrm{C}$., El afecto sin objeto y la escritura fragmentaria. Una lectura del desasosiego pessoano. Madrid, Universidad Autónoma de Madrid, 2006

Salinas, P., “El concepto de generación literaria aplicado a la del 98", en Literatura española. Siglo XX, Madrid, 1970.

Sánchez Verdejo, F., "Breve análisis de la figura de la femme fatale en el cine", en Orisos. Revista de investigación y divulgación cultural, n² 2, 2013.

Santamaría Blasco, L., "Asesinos victorianos en la República de Weimar. De psicho Killers y femme fatales, en Herejía y Belleza", en Revista de estudios culturales sobre el movimiento gótico, n² 2, 2014.

Savignano, A., "El 98 y la filosofía europea", en Anuario Filosófico, n 31, 1998.

Segura, A., La acedia y el decadentismo fine-secular de Huysmans, en EPOS, XXXIV, 2018

Schopenhauer, A., Parerga y Paralipómena, II, Madrid, Trotta, 2009

Schopenhauer, A., El amor, las mujeres y la muerte (trad. a cargo de López White), en www.schopenhauer-web.org, 2008. Consulta, junio de 2021.
Simón Rodríguez, E., Democracia vital. Mujeres y hombres hacia la plena ciudadanía, Madrid, Narcea, 1999

Showalter E., Sexual Anarchy: Gender and Culture at the Fin de Siecle. Nueva York, Penguin, 1990.

Sobejano, G., Nietzsche en España, Madrid, Ed. Gredos, 1967

Tatar, M., Lustmord. Sexual Murder in Weimar Germany, Princeton, Princeton University Press, New Jersey, 1995

Trigaud, J.M., Persona ou la justice au double visage, Génova, Studio Editoriale di Cultura, 1990.

Trudgill, E. Madonnas and Magdalens: The Origins and Development of Victorian Sexual Attitudes, Londres, Heinemann Ltd, 1976,

Walkowitz, J., La ciudad de las pasiones terribles. Narraciones sobre el peligro sexual en el Londres victoriano, Madrid, Ediciones Cátedra, 1999. 
